\title{
How Does Directors' Remuneration and Board Structure Impact on Firm Performance in Malaysia Telecommunication Industry?
}

\author{
Noor Nasyikin Md Zain, Noor Ayuernie Ibrahim, Aza Azlina Md. Kassim, and Fazilah Tamsir
}

\begin{abstract}
Remuneration is broadly used as an incentive that affects decisions made and strategies planned by directors which cause great impact on firm performance. This study aims to investigate the relationship among directors' remuneration, board size, and firm performance of Malaysian listed companies under Telecommunication Industry. The firm's performance is measured by return on assets (ROA). This study consists of 25 observations with a sample of five Malaysian listed companies for the period of 2013 to 2017. The regression results show directors' remuneration and board size have negative relationship with firm performance. This suggests that high remuneration does not able to motivate and retain directors in order to perform their duty and work harder for the best interest of shareholders. The result also shows that larger boards unable to ensure effectiveness in monitoring management and thus, did not associated with better performance. For future research, it is recommended that this study be expanded using more samples from other industries and other measurement of firm performances such as growth and ratings.
\end{abstract}

Index Terms - Board Size; Directors' Remuneration; Firm Performance; Telecommunication Industry; Return on Assets

\section{INTRODUCTION}

Corporate governance is principally on the structure of relationship within an organisation which is directed at best practice in the overall interest of the firm and its dispersed stakeholders [1]. Corporate governance has many benefits and effects; it creates more open, transparent society, corruption prevention, rule of law with fairness and order and promoting ethical wealth creation [2]. Despite the importance of the role of board of directors in corporate governance, little is known about the nature of the collective body of directors in recent years and how they are remunerated.

According to the agency theory [3] directors are selfinterested and may behave opportunistically at the expense of shareholders' interests. Therefore, corporate boards of directors are supposed to confine director opportunism and align the directors' interests with that of shareholders by

Noor Nasyikin Md Zin is a Senior Lecturer with the Faculty of Business and Accountancy, Universiti Selangor, Seksyen 7, 40000 Shah Alam, Selangor, Malaysia (e-mail: nasyikin@unisel.edu.my).

Noor Ayuernie Ibrahim is a Part Time Lecturer with the Faculty of Business and Accountancy, Universiti Selangor, Seksyen 7, 40000 Shah Alam, Selangor, Malaysia (e-mail: noor ayuernie@yahoo.com).

Aza Azlina I an Associate Professor with the Faculty of Business and Accountancy, Universiti Selangor, Seksyen 7, 40000 Shah Alam, Selangor, Malaysia (e-mail: aza azlina@unisel.edu.my)

Fazilah Tamsir is a Senior Lecturer with the Faculty of Business and Accountancy, Universiti Selangor, Seksyen 7, 40000 Shah Alam, Selangor, Malaysia (e-mail: fazilah@unisel.edu.my) better monitoring through effective corporate governance mechanisms, and designing efficient pay contracts that typically link directors' compensation with firm performance. Besides, the total number of directors including the chairman on the board has a significant research in terms of its relationship with firm performance

[4]. In agency theory, the corporate boards, assuming the power to look after the firm, involve in arm's length transaction with CEO and design such compensation plans which provide CEO with efficient incentives to maximize the shareholder value, and hence reduce moral hazard problem arising from separation of ownership from control [5]. This predicts a positive link between CEO compensation and firm performance.

Much of the research focuses on the question whether directors' compensation contracts can be justified in terms of their contribution to the firm financial performance [6]. The level of directors' remuneration received in Malaysia has attracts high attention among Malaysian netizen and prospective investors [7]. The high remuneration received by directors' of corporate bodies have been questioned as to if such remuneration are justified by the underlying economic performance of the company in question. These debates have tended to focus on two areas: the overall level of directors' remuneration, corporate size, and the suitability of performance measures linking directors' remuneration with performance [8]. The debate on executive directors' remuneration has been driven by the view that some directors, and especially those directors in the telecommunication industry, are being overpaid to the detriment of the shareholders, other employees, and the company as a whole [9]. The need for the practice of good corporate governance is therefore not only necessary but could be defeated when directors' remunerations are not questioned.

This research is significant for several reasons. First, the communication of directors' remuneration promotes real transparency and is central to shareholders ability to exercise their ownership rights on an informed basis. Therefore, providing comprehensive and detailed remuneration information may mitigate the information asymmetry issues between management and stakeholders. Second, it has been suggested by [10] that executive and board remuneration levels continue to increase in Malaysia. This phenomenon is crucial, especially to the shareholders, in ensuring that the executive director is reasonably paid according to their performance. Therefore, the thrust of this study therefore is to investigate the relationship among directors' remuneration, board size, and firm performance in Malaysian Telecommunication industry. 


\section{LITERATURE REVIEW}

\section{A. Theoretical Framework}

A theoretical framework guides research, determining what variables to measure, and what statistical relationships to look for in the context of the problems under study [11]. Thus, the theoretical literature helps the researcher see clearly the variables of the study; provides a general framework for data analysis; and helps in the selection of applicable research design. In this study, the Agency Theory and Stewardship Theory guide every aspect of research, from formulation of the research question through operationalization and discussion.

Research on non-executive directors using an agency framework considers their role as monitors in mitigating the agency problem. Reference [3] proposed a theory of the firm (Agency Theory) based upon conflicts of interest between various contracting parties such as shareholders, company managers, and debt holders. They further specified the existence of agency costs which arise owing to the conflicts either between managers and shareholders (agency costs of equity) or between shareholders and debt holders (agency costs of debt) [3].

According to this theory, the principal will delegate some or all of the decision-making authority to the agent. In practice, shareholders from most public listed companies delegate the decision-making authority to the board of directors. In turn, the board of directors delegates power to the chief executive officers (CEO). The agency problems arise because of the impossibility of perfectly contracting for every possible action of an agent whose decisions affect both his own welfare and the welfare of the principal. The agency theory argues that an agency relationship exists when shareholders (principals) hire managers (agents) as the decision makers of the corporations. However, agency problems arise because managers will not solely act to maximize the shareholders' wealth; they may protect their own interests or seek the goal of maximizing companies' growth instead of earnings while making decisions. Inefficiency may be reduced as managerial incentives to take value maximizing decisions increased [3].

Stewardship Theory assumes a strong relationship between the success of organization and shareholders' satisfaction [13]. A steward is defined by [14] as one who protects and maximizes shareholders wealth through firm performance, because by so doing, the steward's utility functions are maximized. In this perspective, stewards are company executives and managers working for the shareholders with the aim of protecting and generating profits. Managers are viewed as stewards who act in the best interest of owners of the firm and whose behaviors are aligned with the objectives of their principals.

However, the Stewardship Theory does not seem to agree with the agency theory when it comes to the managerial compensation system drawn by the agency framework [15]. Meanwhile under the agency framework the senior management is described as self-serving and distinctive, but the stewardship sees them as dependent and would act together in a team. This is because in the Stewardship Theory, senior management will not allow individual inspiration to supersede their role to deal with the assets of the entity for the betterment of the organization. Hence, senior management will focus and maintain a reasonable management team for the organization that can maximize the wealth of shareholders. Thus, Stewardship Theory emphasizes on the requirement for compensation agreements to alleviate the agency conflict between the shareholders and managers. It also highlights the aspects of human capital in term of knowledge, skill, capabilities, and experience and so forth. Moreover, it significantly decreases the need to adjust their remuneration packages with the organization performance [16].

\section{B. Empirical Evidence on Directors' Compensation and Firm Performance}

Remuneration is a form of salaries, allowances or incentives and bonuses received by the employee [17]. Broadly speaking, remuneration obtained consists of cash remuneration and any other remuneration based on shares that are associated with short-term performance and long term directors' compensation. Directors' remuneration is commonly used as an incentive that can affects strategies planned and decisions made by directors which cause great impact on firm performance and profitability [18]. Reference [11] suggested that directors' remuneration has little impact on the firm performance from the perspective of a shareholder and investor.

Research on directors' compensation mainly concerns with the extent to which the directors are remunerated in ways that align their interests with those of their firms' owners. Reference [3] underscore the importance of incentive alignment solution to agency problems when they propose that executive compensation should be designed in such a way that can reduce the degree of conflict of interest between shareholders and managers. Theoretically, effective compensation system is the one that motivates managers to forego their opportunistic behaviors and focus on value maximization activities [19].

Several studies investigate the impact of directors' remuneration on the firm performance. For instance, [20] observed the link between difference aspects of firm performance and CEO compensation across different industries, which found that CEO compensation have direct relation with the financial measures of the performance of the company. In the Malaysia context, [21] investigates the extent of Malaysian directors' remuneration disclosure in the annual reports based on individual pay for each director, band of pay, linkage to performance, and components of pay. Their results reveal that most of the sampled firms communicate information about the directors pay in bands of RM50,000, together with the narration of linkages between the directors pay and performance in their annual reports. However, not many companies disclose information about individual directors pay, or separately disclose the salary and bonus components. Similar result was obtained by [22]. They found that in Malaysian family firms, directors' remuneration significantly affects the board motivation in improving firm performance.

Several other studies also found a strong and positive correlation between directors' compensation and profitability [9], [23], and [24]. Moreover, [25] found that alteration in the remuneration structure of CEOs significantly affected the firm performance. Recently, [26] found that the board of directors' pay has a positive and significant relationship with firm performance among UK FTSE 100 non-financial companies using data from the period 2012 to 2015. Contrary, [27] found that director 
remuneration is negatively related to monitoring characteristics such as director independence, suggesting possible agency considerations, as effective monitors of top management are paid less. While [28] reported the absence of pay-performance relationship among the smaller sample firms and business group affiliated firms. Based on the above discussion, the first hypothesis can be stated as follows:

H1: There is a positive relationship between directors' remuneration and firm performance.

\section{Empirical Evidence on Board Size \& Firm Performance}

Considering that the Agency Theory [3] supports any mechanism that solves the conflict of interest between managers and owners, the board of directors is seen as a good tool to align their respective competing interests [29]. Board size is an important attribute of board structure. According to [30], the size of board affects the monitoring, controlling and decision-making in a firm. The board size is calculated by the number of directors sit on the board of the company which is a crucial indicator for its effectiveness. Increase in the size of the board will likely enhance to board's effectiveness in offering adequate support in reducing agency cost that results from inefficient management of the firm which will eventually improve the financial results of the companies [3].

Studies to date, including those where no relationship has been found to exist at all, have produced mixed results. There are studies that have found a positive relationship between size and profitability. For instance, [31] argued that the larger board size increases firm's financial performance. The possible explanation that the board of directors may compose of members who are more expert and capable to undertake vital decisions. This eventually will be harder for a powerful CEO to control the decisions of the board of directors. The outcome could improve governance; more especially improve efficiency of firm's management and enhance its financial performance. Reference [32] further argued that larger boards could benefit the company through advice and counsel. Based on samples of non-financial firms, [33] - [35] conclude that some firms may benefit from large board of directors.

Moving forwards, [4] found that board size is positively related to performance. According to them, small board is more effective and performs better and effective in term of costs savings. Reference [36] found that board size has a positive impact on operational efficiency, suggesting that a large number of directors positively influence the rationalization of operational costs. [37] investigate the impact of board size on performance for a sample of 30 commercial banks from 2008 to 2012 in Turkey. The results of panel fixed effects regression suggest that board size has a significantly positive effect on bank's financial performance. Reference [38] found that there was a positive and insignificant relationship between board size and financial performance of listed firms at Nairobi Security Exchange for a period of three years (2010 to 2012). Similarly, [39] found that board size is significantly and positively related to firms' performance measured using return on assets (ROA) among industrial listed firms on the Amman Stock Exchange, Jordan for the year 2013.

On the other hand, majority of studies in the literature suggest negative association between board size and firm performance. Board size is negatively related to firm value due to the fact that firms with larger board of directors tend to use their assets less efficiently and earn less profit [40]. Reference [41] found that board size has a negative impact on firm value in Singapore and Malaysia. Using a large sample of UK listed firms and controlling for different types of endogeneity, [42] found that board size has a strong negative effect on firm profitability measured by Tobin's Q and stock returns. A study by [43] revealed a negative association between board size and performance of firm, measured by ROA and financial $\mathrm{Q}$ for firms listed on the Irish Stock Market. Based on a sample of Canadian service firms listed on Toronto Stock Exchange, [44] uncovered a negative relation between board size and firm profitability. [45] investigate a sample of 257 Singaporean non-financial listed firms for the period of 2008 to 2011. They conclude that the board size has a significantly negative influence on firm performance. Similarly, [46] found that board size has significant negative impact on the performance of banks in Nigeria. They suggested that an increase in board size would lead to a decrease in ROE and ROA. In the pharmaceutical industry of Bangladesh, [47] also found that there is a significant negative relation between board size and firm's financial performance measured using Tobin's $Q$ and return on asset (ROA).

Based on the inconsistent findings have been documented in the board size impact on firm performance measures of firms, this study conjectures:

$\mathbf{H}_{2}$ : There is a positive relationship between board size and firm performance.

\section{RESEARCH METHODOLOGY}

This study is a longitudinal design covering a time period of five years from 2013 to 2017. A total of five public listed companies in the telecommunication industry quoted on the Bursa Malaysia as at $31^{\text {st }}$ December, 2018 constituted the population. A sample of 25 observations was used since these firms usually publish regular annual financial reports and accounts. Historical data used were obtained from published annual reports and accounts of the sampled firms.

\section{A. Dependent and Independent Variables}

In this study, return on assets (ROA) has been adopted to measure firm's financial performance as the dependent variable. Return on Assets (ROA) (an accounting based performance measure) is calculated as "Earnings before Interest and Taxes" (EBIT) scaled by the book value of total assets. Based on the existing relevant empirical studies, the independent variables for this study are directors' remuneration and board size. Directors' remuneration is measured by log of directors' salaries plus benefits. Board size represents the total number of directors on the board.

\section{B. Statistical Analysis}

In order to examine the relationship between directors' remuneration, board size, and firm performance, the following model is developed:

$Y_{i, t}=\alpha+\beta_{1} R E M_{i, t}+\beta_{2}$ BSize $_{i, t}+\varepsilon$

Where, 
$Y_{i, t}$ is return on asset (ROA) for $i$ firm at time $t$, $R E M_{i, t}$ is directors' remuneration for $i$ firm at time $t$,

$B S i z e_{i, t}$ is the board size for $i$ firm at time $t$,

$\alpha$ is the intercept, $\beta i$ is the regression coefficient and $\varepsilon$ is the error term,

The subscript $i$ represents the different firms and $t$ represents the different years.

The statistical device employed is the standard multiple regression for the purpose of testing the relationship that exists between directors' remuneration, board size, and firm performance. Data collected were estimated with econometric software of SPSS version 24.

\section{FINDINGS AND DISCUSSION}

\section{A. Descriptive Statistics}

This section presents the descriptive results. The results are presented by the trend analysis. This study sought to establish the directors' remuneration of all listed firms in the telecommunication industry across a period of five years. Fig. 1 shows that the amount of directors' remuneration increased or grew across the years. This finding implies that there is consistent increase or growth in the pay for directors in the public listed companies in the telecommunication industry.

Directors' Remuneration ('000)

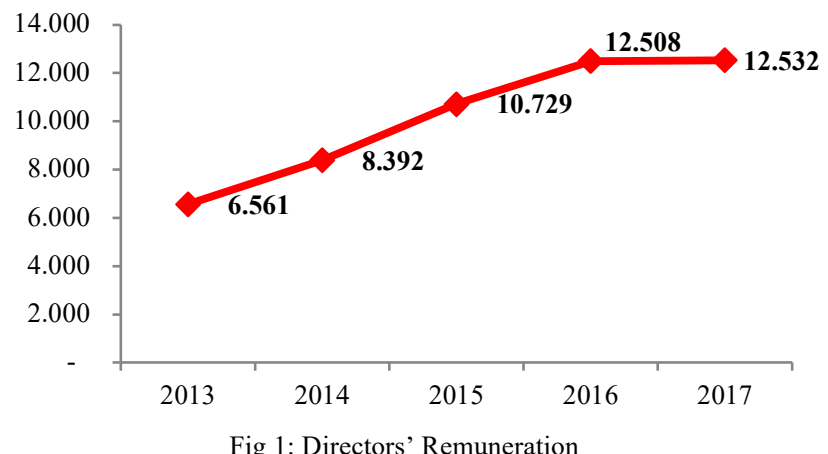

Results in Fig. 2 shows that number of board size increased as the years passed. Results indicate that the number of board size increased from 9.6 in 2013 and gradually increase to a peak of 10.6 in 2016. This number is slightly decreased to 10.4 in 2017 . The findings imply that as the firms grew the number of board members also increased hence more experience and more competence.

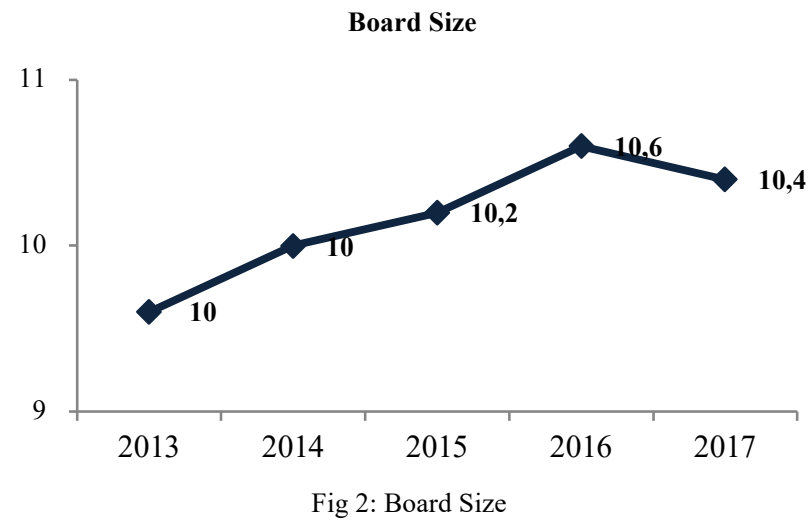

Results in Fig. 3 shows that the average mean of return on assets (ROA) decreased gradually from 20.39 percent in 2013 to 9.57 percent in 2016 and a slight increase to 11.03 percent in 2017 . The findings imply that the profitability of firms increased in the latest years, most probably due to good governance practices.

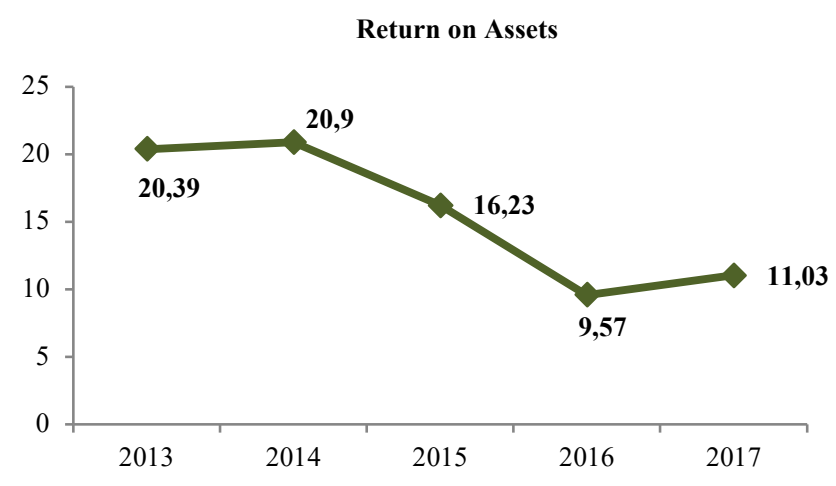

Fig 3: Return on Assets

\section{B. The Influence of Directors' Compensation and Board Size towards Firm Performance}

This section will discuss the results of main research objective, i.e. to investigate the relationship among directors' remuneration, board size, and firm performance in Malaysian Telecommunication industry. The summary results of the standard multiple regression analysis on the relationship between these variables is presented in Table 1. The regression of model $(F(2,25)=11.022, p$ value $=$ $\left..000^{* * *}\right)$ is significant at the $1 \%$, and the overall fit of the model is moderate with $\mathrm{R}^{2}$ value is $50.1 \%$ of the variation in the firm performance. This indicates that the predictor variables in the model explained for approximately $50.1 \%$ of the total variability in the firm performance of Malaysian telecommunication industry.

TABLE 1: THE RELATIONSHIP AMONG DIRECTORS' REMUNERATION, BOARD SIZE, AND FIRM PERFORMANCE

\begin{tabular}{|c|c|c|c|}
\hline & $\begin{array}{c}\text { Std. Beta } \\
\text { Co-eff }\end{array}$ & $t$-stat & $p$ value \\
\hline Intercept & & 3.659 & $.001^{* * *}$ \\
\hline $\begin{array}{l}\text { Director's } \\
\text { Remuneration }\end{array}$ & -0.415 & -2.018 & $.005^{* * *}$ \\
\hline Board Size & -0.356 & -1.734 & $.009^{* *}$ \\
\hline \multicolumn{4}{|c|}{ Model Summary: } \\
\hline $\mathrm{R}^{2}$ value & & & $50.1 \%$ \\
\hline \multicolumn{4}{|l|}{ Anova Results: } \\
\hline F-value & & & 11.022 \\
\hline Sig. value & & & $.000^{* * *}$ \\
\hline Obs. & & & 25 \\
\hline
\end{tabular}

Hypothesis $\mathrm{H}_{1}$ conjectures that there is a positive relationship between directors' remuneration and firm performance. Result in the Table 1 shows that there is a strong statistically significant and negative relationship between directors' remuneration and firm performance $(t$ statistic $=-2.018, p$ value $<.05)$. Therefore, this result leads 
to the rejection of $\mathrm{H}_{1}$. This result indicates that higher pay to the directors have a negative impact to the firms' performance. The finding of this study is consistent with a research by [27] who found that director remuneration is negatively related to monitoring characteristics.

Further, hypothesis $\mathrm{H}_{2}$ predicts that there is a positive relationship between board size and firm performance. Result in the Table 1 reveals that the relationship between board size and firm performance is negative and statistically significant $(t$-statistic $=-1.734, p$ value $<.05)$. Therefore, $\mathrm{H}_{2}$ is not supported. This result indicates that larger board size will reduce the performance of PLCs. This outcome is similar as what has been found in other studies such as [40] - [47]. Board size is negatively related to firm performance perhaps due to the fact that firms with larger board of directors tend to use their assets less efficiently and earn less profit.

\section{CONCLUSION}

The link between corporate governance and firm performance has been issue of considerable focus. Since corporate governance practices are aimed towards ensuring that affairs of firms are directed and controlled, the manner in which directors are remunerated become important. With corporate governance, how directors are remunerated is expected to be credible. Hence directors' remuneration is based on the overall interest of the firm and for the crucial roles they perform in the firm. All protocols should be observed in the firms in the way directors are remunerated based on corporate governance practices of the firm. This study therefore conclude that with good corporate governance the manner in which firm financial resources are judiciously spent and directors' remuneration are fixed based on the laid down practices of the firm. Besides, firms also need to observe the numbers of directors sit on the board to ensure that they played a monitoring role in the firm.

The objective of the study is to investigate the relationship among directors' remuneration, board size, and firm performance in Malaysian PLCs under the Telecommunication industry. The study is based on a longitudinal design of five PLCs covering a time period of five years (2013 to 2017). This study reveals that is an increasing trend in directors' remuneration and board size, while decreasing trend is observed for return on assets (ROA) over the five years. This study suggests that directors' remuneration has a significant negative impact on the performance of telecommunication PLCs. This study observes that the larger the firms the higher remuneration package paid to the directors. Hence, this finding indicates that high compensation packages to the directors of PLCs under the telecommunication industry may impair the directors' judgments, giving managers the advantage of being able to pursue their own interests at the expense of performance. Also, higher compensation may lead to the practice of 'mutual back scratching' by directors who collectively propose better packages for each other at the expense of performance [48].

Besides, the results show that board size has a significant negative impact on the performance of PLCs in telecommunication industry. This negative relationship with large boards is due to the communication, coordination and decision-making problems that negate the benefits arising from the collective wisdom of the board members. The finding of this study is consistent with [49] which also reported that board size is negatively associated with firms' financial performance and the quality of decision-making. In line with that, this study recommends that a small but representative board size for telecommunication industry in Malaysia. This is consistent with suggestion by [50] who suggests that a limited number of board members are important for effective corporate governance. Reference [51] demonstrated that smaller boards are more effective in monitoring management and thus associated with better performance. Perhaps, the smaller board size, the better performance can be achieved, and would provide extra board monitoring and subsequently corporate players could perform their duties effectively and efficiently in enhancing shareholders value.

\section{A. Implications of the Study}

The study makes important contributions to extant literature and has implications for practitioners and policy makers.

The finding of the relationship between directors' remuneration and firm performance is contradicted with the notion of the stewardship theory, whereby directors should be performing better in the future on the basis of prior amounts and structure of remuneration packages. Hence, the key implication of this study is that greater firm performance can be achieved by pursuing policy reforms regarding incentive alignment of executive pay under a good structure of corporate governance. For example, in order to get better performance, the incentives should be substantial for the board of directors in order to align with the firm performance. Moreover, firms should reduce the number of board of directors and ensure that they play monitoring role towards firms' operations. Additionally, this study provides evidence that for better performance, the PLCs in the telecommunication industry should need to improve their corporate governance mechanism in general. In terms of policy implications, the finding of a negative relationship between board size and firms performance urged to recommend that the policy maker need to focus their attention on reducing board size to an optimal level.

Although this study reported significant and reliable findings, it is limited in some aspects. For example, it includes a limited number of observations due to the short sample period. Moreover, the study misses some important variables like external corporate governance, board member features, and equity-based remuneration due to nonavailability of data. Therefore, future studies may provide new insights by applying this study's framework in cross countries especially in the developing countries. Future study also may consider other performance indicators including return on equity (ROE), earnings per share (EPS), Tobin's Q and return on investment (ROI). Methodologically, more knowledge might be gathered by future researchers by carrying out some structured and unstructured interviews with the board of directors, owners, and regulatory authorities relating to the corporate governance and pay-performance relationships. 


\section{REFERENCES}

[1] A. S. Omoye and K. O. Ogiedu, "Corporate governance attributes, firm performance and directors' remuneration," Corporate Governance, vol. 7, no. 4, pp. 35-46, 2016.

[2] D. Jerab, "The effect of internal corporate governance mechanisms on corporate performance," Journal of Business \& Policy Research, vol. 5 , no. 1 , pp. $110-122,2011$.

[3] M. C. Jensen and W. Meckling, "Theory of the firm: Managerial behaviour, agency costs and capital structure," Journal of Financial Economics, vol. 3, pp. 305-360, 1976.

[4] R. B. Adams and H. Mehran, "Bank board structure and performance: Evidence for large bank holding companies," Journal of Financial Intermediation, vol. 21, no. 2, pp. 243-267, 2012.

[5] L. A. Bebchuk and J. A. Fried, "Executive compensation as an agency problem," Journal of Economic Perspectives, vol. 17, pp. 71-92, 2003.

[6] M. Van Essen, P. P. Heugens, J. Otten, and J. H. van Oosterhout, “An institution-based view of executive compensation: A multilevel metaanalytic test," Journal of International Business Studies, vol. 43, no.4, pp. 396-423, 2012.

[7] S. P. Lee and M. Isa, "Directors' remuneration, governance and performance: The case of Malaysian banks," Managerial Finance, vol. 41, no. 1, pp. 26-44, 2015.

[8] R. Abdul Rahman and R. J. Limmack, "Corporate acquisitions and the operating performance of Malaysian companies," Journal of Business Finance \& Accounting, vol. 31, no. 3/4, pp. 359-400, 2004.

[9] E. Opata and Z. Awino, "Corporate governance practices and performances in the mobile and data services companies in Rwanda," International Journal of Public Policy and Administration, vol.1, no.1, pp. 21-42, 2017.

[10] Ernst and Young, "Executive and board remuneration continues to increase in Malaysia," from http://www.ey.com/MY/en/ Newsroom/News-releases/Newsroom. 2009.

[11] R. Aggarwal and A. Ghosh, "Director's remuneration and correlation on firm's performance: A study from the Indian corporate," International Journal of Law and Management, vol. 57, no. 5, pp. 373-399, 2015.

[12] H. E. Ryan and R. A. Wiggins, "Who is in whose pocket? Director compensation, board independence, and barriers to effective monitoring," Journal of Financial Economic, vol. 73, no. 3, pp. $497-$ $524,2004$.

[13] F. Zhang, L. Wei, J. Yang and L. Zhu, "Roles of relationships between large shareholders and managers in radical innovation: A stewardship theory perspective," Journal of Product Innovation Management, vol. 35, no. 1, pp. 88-105, 2018.

[14] Davis, J. H., Schoorman, F. D. and L. Donaldson, "Davis, Schoorman, and Donaldson reply: The distinctiveness of Agency Theory and Stewardship Theory," The Academy of Management Review, vol. 22, no. 3, pp. 611-613, 1997.

[15] M. Alam, "Stakeholder Theory. Methodological Issues in accounting research: Theories," Methods and Issues, vol. 6, no. 1, pp. 207-222, 2006.

[16] Hendry, K., \& Kiel, G. C. "The role of the board in firm strategy: Integrating agency and organisational control perspectives,' Corporate Governance: An International Review, vol. 12, no. 4, pp. 500-520, 2004

[17] I. Oviantari, "Directors and commissioners remuneration and firm performance: Indonesian evidence," Journal of Business and International Research, vol. 2, no. 1, pp.1-16, 2011.

[18] M. W. Mohd Razali, N. S. Yee, J. Y. T. Hwang, A. H. B. Tak, and N. Kadri, 'Directors' remuneration and firm's performance: A study on Malaysian listed firm under consumer product industry," International Business Research, vol. 11, no. 5, pp. 102109, 2018.

[19] Z. Ramly and H. M. A. Rashid, "Critical review of literature on corporate governance and the cost of capital: The value creation perspective," African Journal of Business Management, vol. 4, pp. 2198-2204, 2010.

[20] T. Jeppson, W. Smith and R. Stone, "CEO Compensation and Firm Performance: Is there any Relationship?" Journal of Business \& Economics Research, vol. 7, pp. 81-94, 2009.

[21] N. Aripin, B. Salim, H. Kamardin, and N. C. Adam, "The communication of director's remuneration," Procedia-Social and Behavioral Sciences, vol. 65, pp. 321-326, 2012.

[22] B. J. Syaiful, A. A. W. Effiezal, and K. James, "Director remuneration and performance in Malaysia family firms: An expropriation matter?" World Review of Business Research, vol. 2, no. 4, pp. 204-222, 2012.
[23] E. Aslam, R. Haron, and M. N. Tahir, "How director remuneration impacts firm performance: An empirical analysis of executive director remuneration in Pakistan," Borsa Istanbul Review, vol. 19, no. 2, pp. 186-196, 2019.

[24] P. Kent, K. Kercher, and J. Routledge, "Remuneration committees, shareholder dissent on CEO pay and the CEO pay-performance link," Accounting and Finance, vol. 58, no. 2, pp. 445-475, 2018.

[25] T. Perry and M. Zenner, "Pay for performance? Government regulation and the structure of compensation contracts," Journal of Financial Economics, vol. 62, no. 3, pp. 453-488, 2001

[26] A. J. Alqatan, I. Chbib, and K. Hussainey, "How does board structure impact on firm performance in the UK?" Corporate Board: Role, Duties and Composition, vol. 15, no. 2, pp. 18-27, 2019.

[27] L. Goh, and A. Gupta, "Remuneration of non-executive directors: Evidence from the UK. The British Accounting Review, vol. 48, no. 3, pp. 379-399, 2016.

[28] M. Raithatha and S. Komera, "Executive compensation and firm performance: Evidence from Indian firms," IIMB Management Review, vol. 28, no. 3, pp. 160-169, 2016.

[29] R. E. Freeman, "Strategic Management: A Stakeholder Approach," Boston: Pitman, 1984

[30] M. Kılıç and C. Kuzey, "The effect of board gender diversity on firm performance: Evidence from Turkey," Gender in Management: An International Journal, vol. 31, no. 7, pp. 434-455, 2016.

[31] A. Kyereboah-Coleman and N. Biekpe, "The relationship between board size, board composition CEO duality and firm performance experience from Ghana," Working Paper. 2005

[32] C. Dalton and D. Dalton, "Boards of directors: Utilizing empirical evidence in developing practical prescriptions," British Journal of management, vol. 16, no. 1, pp. 91-97, 2005.

[33] A. Boone, L. Field, J. Karpoff, and C. Raheja, "The determinants of corporate board size and composition: An empirical analysis," Journal of Financial Economics, vol. 85, no. 1, pp. 66-101, 2008. Doi: 10.1016/j.jfineco.2006.05.004.

[34] J. S. Linck, J. M. Netter and T. Yang, "The determinants of board structure," Journal of Financial Economics, vol. 87, pp. 308-328, 2008. Doi: 10.1016/j.jfineco.2007.03.004.'

[35] K. Lehn, P. Sukesh, and Z. Mengxin, "Determinants of the size and structure of corporate boards: 1935-2000," Financial Management, 38(4), 747-780. 2009. Doi: 10.1111/j.1755-053X.2009.01055.x.

[36] V. Ongore and P. K'Obonyo, "Effects of selected corporate governance characteristics on firm performance: Empirical evidence from Kenya," International Journal of Economics and Financial Issues, vol. 1, no, 3, pp. 99-122, 2011.

[37] O. Isik and A. R. Ince, "Board size, board composition and performance: An investigation on Turkish banks," International Business Research, vol. 9, no. 2, pp. 74-84, 2016.

[38] O. Ngulumbu, and J. Aduda, "Relationship between board composition and financial performance of companies listed at the Nairobi Securities Exchange," American Journal of Finance, vol. 1, no. 2, pp. 72-90, 2017.

[39] A. A. M. Qadorah and F. H. B. Fadzil, "The relationship between board size and CEO duality and firm performance: Evidence from Jordan," International Journal of Accounting, Finance and Risk Management,vol. 3, no. 3, pp. 16-20, 2018.

[40] D. Yermack, "Higher market valuation of companies with a small board of directors," Journal of Financial Economics, vol. 40, no. 2, pp. 185-211, 1996. Doi: 10.1016/0304-405X(95)00844-5.

[41] Y. T. Mak and Y. Kusnadi, "Size really matters: Further Evidence on the negative relationship between board size and firm value," PacificBasin Finance Journal, vol. 13, pp. 301-318, 2005. Doi: 10.1016/j.pacfin.2004.09.002.

[42] P. M. Guest, "The impact of board size on firm performance: Evidence from the UK," The European Journal of Finance, vol. 15, no. 4, pp. 385-404, 2009.

[43] V. O'Connell and N. Cramer, "The relationship between firm performance and board characteristics in Ireland," European Management Journal, vol. 28, no. 5, pp. 387-399, 2010. doi: 10.1016/j.emj.2009.11.002.

[44] A. Gill and N. Mathur, "The impact of board size, CEO duality, and corporate liquidity on the profitability of Canadian service firms," Journal of Applied Finance \& Banking, vol. 1, no. 3, pp. 83-95, 2011.

[45] T. Nguyen, S. Locke, and K. Reddy, "A dynamic estimation of governance structures and financial performance for Singaporean companies," Economic Modelling, vol. 40, pp. 1-11, 2014. Doi: 10.1016/j.econmod.2014.03.013.

[46] A. Bebeji, A. Mohammed, and M. Tanko, "The effect of board size and composition on the financial performance of banks in Nigeria," African Journal of Business Management, vol. 9, no. 16, pp. 590-598, 2015. 
[47] S. D. Nath, S. Islam, and A. K. Saha, "Corporate board structure and firm performance: the context of pharmaceutical industry in Bangladesh," International Journal of Economics and Finance, vol. 7, no. 7, pp. 106-115, 2015

[48] I. E. Brick, O. Palmon, and J. K. Wald, "CEO compensation, director compensation, and firm performance: Evidence of cronyism?" Journal of Corporate Finance, vol. 12, no. 3, pp. 403-423, 2006.

[49] B. E. Hermalin and M. S. Weisbach, "Introduction: The Study of Corporate Governance," In The Handbook of the Economics of Corporate Governance (vol. 1, pp. 1-15). North-Holland. 2017

[50] M. Jensen, "Modem industrial revolution, exit, and the failure of internal control systems," Journal of Finance, vol. 3, no. 4, pp. 83180, 1993.

[51] A. Bermig, "Who is the Better Monitor? The impact of female board of Directors, Board Composition, and Board Size on Earning Management," Paderborr: Universtiy of Padeborr, 2010.

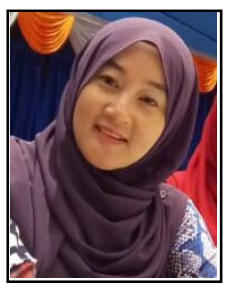

Noor Nasyikin Md. Zain is a senior lecturer at the Faculty of Business and Accountancy, Universiti Selangor (UNISEL). She was born in Kedah on $16^{\text {th }}$ January 1975 .

She completed her studies in Master in Accountancy from Universiti Teknologi MARA (UiTM), Malaysia in 2002 and also holds a Bachelor Degree in Business Administration, majoring in Finance from Universiti Utara Malaysia (UUM) in 1997. She has over 20 years' experience in teaching accounting courses. Her specialization is in the area of taxation. Her area of research includes education, financial reporting and corporate governance.

Ms. Md. Zain is a member of Malaysian Institute of Accountant (MIA) and Malaysian Accounting Association (MyAA). She also received research funding from UNISEL.

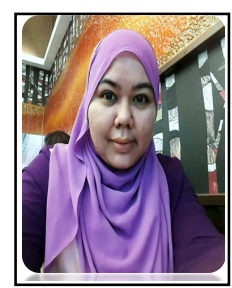

Noor Ayuernie Ibrahim is a part time lecturer at the Universiti Selangor (UNISEL), Malaysia. She was born in Kelantan on $23^{\text {rd }}$ May 1982. She received her Master in Accounting from Universiti Teknologi MARA (UiTM), Malaysia on 2010. Her area of research includes financial reporting, management, and earnings manipulation.

Her works has been published in Journal of Economic, Business, and Management; IEEE Symposium on Business, Engineering and Industria Applications (ISBEIA 2012); and IEEE Colloquium on Humanities, Science \& gineering Research (CHUSER 2011). She has been attended five conferences.

Ms. Ibrahim also involved as a reviewer is several journal and conference such as International Journal of Management Science and Engineering Management, Proceeding of the 2013 IEEE Symposium on Business, Engineering and Industrial Applications (BEIAC 2013), Proceeding of the 2013 Colloquium on Administrative Science \& Technology 2013 (CoAST 2013), and Proceeding of the 2012 IEEE Colloquium on Humanities, Science \& Engineering Research (CHUSER 2012).

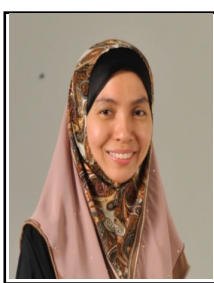

Aza Azlina Md Kassim was born in Shah Alam, Malaysia in January, 1977. She earned a $\mathrm{PhD}$ in Accountancy, MBA (Accountancy), and Bachelor of Accountancy from Universiti Utara Malaysia (UUM), Malaysia.

Currently, she is the Associate Professor in Faculty of Business \& Accountancy, Universiti Selangor (UNISEL), Malaysia. She is the managing editor of Selangor Business Review (SBR) Journal. In UNISEL, she had served as the Dean of Centre for Graduate Studies and Head of Postgraduate Programme. She is also a certified ISO lead auditor. In 2019, she wrote a book titled Corporate Governance: Principles and Practices in Malaysia and published by Oxford Fajar, Malaysia. She published research papers in several journals such as Pertanika Journal of Social Sciences and Humanities, International Journal of Economics and Management and International Journal of Business \& Society. Her areas of interest are corporate governance, earnings management, corporate social responsibility and financial management.

Dr Aza Azlina is a member of Malaysian Institute of Accountant (MIA). In 2018, she has been awarded as the Best Academic Staff of UNISEL. She also received research funding from the Fundamental Research Grant Scheme (Malaysia), Selangor state, and UNISEL.

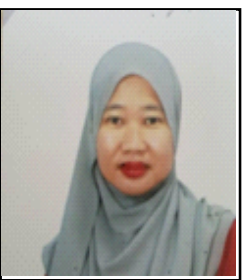

Fazilah Tamsir is a senior lecturer at the Faculty of Business and Accountancy, Universiti Selangor. She was born in Petaling Jaya, Selangor. She holds a Bachelor of Accountancy (Hons) and Master of Accountancy from University Technology Mara.

She has been teaching accounting courses for the past 20 years with specialization in financial reporting. She was formerly the Deputy Dean of Academic, Deputy Dean of Student Affairs and Head of Program Bachelor of Accountancy at the Faculty of Business and Accountancy, Universiti Selangor (UNISEL).

Ms Tamsir is one of the authors of a book published by Oxford Fajar in 2019 titled Corporate Governance: Principles and Practices in Malaysia. She is a member of Malaysian Accounting Association. She also received research funding from UNISEL. 